\title{
Deleuzian Discursive Reterritorialization in the Poetry of Samih El Qassem and Tawfik Zayyad.
}

\author{
Naglaa Saad M.Hassan* \\ Nsm01@fayoum.edu.eg
}

\section{Abstract}

The paper at hand is to read selected poetry of two prominent, albeit understudied, Palestinian poets , Samih Al Qassim and Tawfiq Zayyad in light of Gilles Deleuze's theory of terriotorialization . Starting with an overview of the pertinent theoretical concepts including deterritorialization, re-territorialization, striated space, smooth space, the sedentary and nomad, the study is then to situate the theory in the poetic discourse of the two poets selected. The aim is to show how the theories help highlight the poetic strategies through which the poet enact discursive re-terriorialization. The analysis shows how the poems perform a cartographic function remapping the defaced land and eternalizing in ink what is lost in reality. In addition to the steady emphas is on the image of Palestine as a nurturing "homeland", the two poets are bent on re-territorializing aspects of Palestinian space including cities, villages, landmarks and even normal buildings physically defaced by the Israeli colonizer. eternalizing spatial contour of their country through "naming" certain spatial features of the country- including cities, villages and buildings which were all wiped out from the physical map. By providing a reading of the two poets through a Deleuzian lens, the paper is to wed theory to practice with the double-aim of foregrounding the fruits of using Deleuze's theory in literary analysis on the one hand, and introducing the virtuosic poeticity of two established Arab poets to non-Arab readership on the other. The study is to provide English translations for the Arabic poems selected and will particularly analyze the poetic techniques which help enhance

\footnotetext{
* Associate Professor- English Department -Fayoum University
} 
the thematic vision. To achieve the objectives of the study, the paper is to start with a coverage of the theoretical tenets before undertaking the critical analysis of representative poems.

Keywords:Gilles Deleuze, Felix Guattari, deterritorialization, reterritorialization, striated space, smooth space, Palestinian poetry, resistance, Samih Al Qassim, Tawfiq Zayyad.

\section{Theoretical Background: Deleuze and Guattari and the Non-Fixity of Space}

In their book Thousand Plateaus, Gilles Deleuze and Felix Guattari deconstruct the rigidity associated with space by introducing a new perception of the concept of a territory through a set of novel spatial terms: deterritorialization, reterritorialization, smooth space and striated space. For them, the establishment of a territory with its wide spatial connotations requires a continuous process of deterritorialization which always occurs in relation to a "complementary reterritorialization". Always "connected, and caught up in one another" (Thousand 10), the two processes allow space to remain in a continuous state of flux. Hence, despite its semantic implications, deterritorialization is not suggestive of the complete end of a territory but rather of its new potentialities

For Deleuze and Guattari, the concepts of de- and reterritorialization are closely linked to what they call "smooth space" and "striated space" which they admit to have borrowed from the realm of music. Smooth space, they write, refers to space which is "occupied without being counted", and striated space crystalizes "space that is "counted, in order to be occupied" (Thousand 399). Hence, striated space is "limited and limiting ... limited in its parts, which are assigned constant directions, ... oriented in relation to one another, divisible by boundaries; ...[and] limiting... in relation to the smooth spaces it "contains,"

(Deleuzian Discursive Reterritorialization..)Dr. Naglaa Saad M. Hassan 
whose growth it slows or prevents, and which it restricts or places outside" (Thousand 422). To clarify their idea, Deleuze and Guattari liken both kinds of space to the boards of two games: Chess and Go. As is the case in Go game, the question in smooth space is one of "arraying oneself in an open space... the movement is not from one point to another, but becomes perpetual, without aim or destination, without departure"(Thousand 389). In the case of striated space, the question is one of "arranging a closed space for oneself, ... of going from one point to another, of occupying the maximum number of squares with the minimum of pieces" (Thousand 389). "Chess codes and decodes space", they add, "whereas Go proceeds altogether differently, territorializing or deterritorializing it (make the outside a territory in space; consolidate that territory by the construction of a second, adjacent territory; deterritorialize the enemy by shattering his territory from within; deterritorialize oneself by renouncing, by going elsewhere" (Thousand 353).

Tying their conceptualization of space to the subject, Deleuze and Guattari argue that there are three different kinds of subjects: the nomad, the sedentary and the migrant. Setting the nomad against both the migrant and the sedentary, they argue that the nomad can be called "the deterritorialized par excellence" (Thousand 421). Contrary to the state of the sedentary whose relationship "with the earth is mediatized by something else, a property regime, a State apparatus ... with the nomad, it is deterritorialization that constitutes the relation to the earth, to such a degree that the nomad reterritorializes on deterritorialization itself" (Thousand 421).

Much to the interest of this study, Deleuze and Guattari widen the scope of their theories beyond geographical spaces. In fact, they apply the concepts to a wide range of disciplines, including language, music, philosophy and mathematics. As

(Deleuzian Discursive Reterritorialization..)Dr. Naglaa Saad M. Hassan 
Richard Samin puts it, striated space is a concept which refers to patterns which "frame, divide or partition intellectual constructions as well as territories" (Visions). On the contrary, "smooth space implies the absence of, or breaking free from, such intellectual or spatial constraints" (Samin ). Such bond between space and the intellectual field is further underlined in the concepts of "war machines" - which, for them, have nothing to do with war "but with a particular way of occupying, taking up space-time, or inventing new space-times" ("Control") . For Deleuze and Guattari, a war machine not only refers to the mechanisms of war and struggle over a territory (with its concomitant mechanisms of de- and re-territorialization) but can also involve any mechanism which defies rules and regulations. They argue that a war machine ... in no way "has war as its object" but rather the emission of quanta of deterritorialization, the passage of mutant flows (in this sense, every creation is brought about by a war machine" (Thousand 251-252). War machines, therefore, include any creative attempt at being and becoming including "artistic movements" and it can be directed against any totalitarian power including "the State apparatus" (Thousand 118). In this way, Deleuze and Guattari tie artistic and literary creation to the mechanisms of space and power. In fact, they openly declare that "the task of literature is not "signifying"; "it has to do with surveying, mapping, even realms that are yet to become" ((Thousand 4-5).

\section{The Pal estinian Issue in Light of Deleuzian Concepts}

The concepts explored above are deemed fruitful in analyzing the Palestinian crisis and the relevant discursive responses to the state of de-territorialization and displacement Palestinian land and people have long been subject to. As commonly known, following the First World War, and in a two-

(Deleuzian Discursive Reterritorialization..)Dr. Naglaa Saad M. Hassan 
way process of massive Jewish immigration and intensive settlement building on the one hand and Palestinian forced exodus and evacuations on the other, the state of Israel, founded on the rubbles of the uprooted Palestinian houses, began to take shape until it was bolstered up by the UN General Assembly 1947 resolution. The creation of Israel, therefore, involved the bifocal act of de and re-territorialization with the striated space of the Palestinian state- already "framed" and "partitioned"determinedly altered into smooth space which in its turn entered into a new stage of striation through which a country within a country was established. Furthermore, Israeli practices had turned Palestinian inhabitants, supposedly sedentary from a Deleuzian perspective, into nomads. Even sedentary subjects- those who opted to remain in occupied Palestine -had to face the continuous threat of uprooting, of severing the relations hip tying them to their own land, a status which positions them as also nomadic.

\section{Palestinian Resistance Poetry: The Discursive War Machines}

Needless to say, the Israeli spatial practices were confronted by armed resistance which went hand in hand with literary resistance. Daniel James Schuster shows how "Palestinians have participated in two types of resistance: 'mild' types of non-violent resistance such as songs, novel and poetry as well as more vocal, open, and confrontational (yet non-violent) ones such as public protests, rallies boycotts and sits-ins" (23). Khalid Hussein also contends that "the most distinguished and significant literary outcome of the Arab-Israeli conflict is the emergence of Palestinian resistance poetry" (196). Following the 1948 Nakbah with its concomitant exodus of huge numbers of Palestinians and the loss of Palestinian nationality for the others who opted to be citizens of the new state of Israel, poetry was at once a weapon and a battleground. Ghasan Kanfani writes that "the short period of silence after the 1948 war was followed by a

(Deleuzian Discursive Reterritorialization..)Dr. Naglaa Saad M. Hassan 
great awakening, and national poetry poured out reflecting the people's national fervor" (3-4). After shedding light on the tyrannical restrictions imposed by Israel on those Palestinians who opted to remain in the occupied land, Kanafani illustrates why it was poetry rather than any other genre which was a primary tool of resistance:

under this hard siege, it is quite easy to realize why poetry was the first harbinger of the resistance call, for poetry spreads from mouth to mouth and lives without publication. This also explains why this poetry was at the beginning restricted to the traditional form which is easier to learn by heart and quicker to appeal to the sentiments (4-5) .

To the same effect, Samih K . Farsoun argues, that in the first wave of Palestinian resistance poetry ${ }^{1}$, which, for him, howe ver started as early as 1936, at the hands of Ibrahim Touran (19171941), Abdul Karim Al Karmi (1907-1980) and Abdulrahim Mahmoud (1913-1948), Palestinian poets followed the model of Pre-Islamic poets, in both form and message assuming the role of " the spokespersons of their people" and fashioning "their poetic creations into powerful aesthetic statements of national defiance

\footnotetext{
${ }^{1}$ For many critics, Palestinian resistance poetry started long before the creation of Israel. Abdel Wahab El Mesiri, for instance, had divided Palestinian resistance poetry into five phases. The first phase continued from the last decades of the nineteenth century through 1908. The second phase was from 1908 to 1920 - the period of Palestinian struggle against the Turks. The third period was from 1920 to 1940 and it witnessed the "grass-roots movement of resistance" against Zionist mechanisms and British colonialism. The fourth period was from 1940 to 1956 and it marked a radical development into a more nationalistic and activist poetry. The Fifth period was from 1956 to 1977 and it marked the birth of intense resistance poetry at the hands of activist writers including Samih Al Qassim, Mahmoud Darwish and Fadwa Touqan
}

(Deleuzian Discursive Reterritorialization..)Dr. Naglaa Saad M. Hassan 
and assertion" (90). The Palestinian Qasida, he adds, "often crystalized political positions in telling lines which were memorized by old and young, stiffened resistance and provided rallying slogans"(90). The significance of Palestinian poetry as a discursive tool of resistance in the continuous struggle against the Israeli spatial and temporal deterritorialization cannot, therefore, be underestimated. In fact, Palestinian poetry has played a major role. As Katja Janßen puts it, following the Palestinian exodus, "performing and creating "Palestine in the poem" as an illocutionary act was a cultural strategy of resisting the hege monic Israeli narrative of the Jewish inscription of the country" (38). If Israel succeeded in re-mapping Palestine, Palestinian poets steadily attempted to re-territorialize the land, to preserve in writing the cartographic and spatial contours of their land. Palestinian poetry emerges as a form of an "ideological struggle", a me ans of fighting colonialism and political repression, or to put it in Deleuzian terms, a way of offsetting the spatial and cultural deterritorialization enacted by Israeli forces. By discursively struggling against the destructive acts of the Israeli colonizer, Palestinian poets have long used writing as war machines to confront the striation of smooth space and the effacement of striated space, two acts through which the geographical and cartographical features of the land have been substantially altered

For many critics - including Ghasan Kanfani, Ami EladBouskila, and Seddik Gohar- the post Nakbah Palestinian literature lost its characteristics as "territory-bound" (EladBouskila 11) and became readily divisible into two categories : one written inside occupied Palestine and the other written outside. Palestinian poetry undertaking the role of spatial-reterriotarialization, one can add, had experienced its bloom beginning from the sixties at the hands of two distinctive groups. The first group, which includes Kamal Nasir, Tawfiq Sayigh, Izz-

(Deleuzian Discursive Reterritorialization..)Dr. Naglaa Saad M. Hassan 
al Adin Al Mansira and Fadwa Tuqan- among others -left the country after the Arab defeat in 1967 and handled their country's crisis from outside. The second group, unmoved by the second exodus, chose to fight from inside, to live as exiles in what turned out to be Israel. At the center of this group are the three pillars of national Palestinian resistance poetry: Mahmoud Darwish (19412008), Samih Al Qassem (1939-2014), and Tawfik Zayyad (19291994). In 1970, however, Darwish, following a one-year- study in the Soviet Union decided to relinquish Israeli citizenship and lead a life of exile outside the occupied homeland wherein remained the two "captive writers" (Slyomovics 171) - Zayyad and $\mathrm{Al}$ Qassim.

\section{Qassim and Zayyad and the Palestinian Discursive Re- territorialization Project}

It is in light of the above categorization that the study focuses on the poetry of Tawfik Zayyad and Samih Al Qassim, the two under-studied highly esteemed poets who continued to live in Israel till the end of their lives. In her study of Palestinian poetry, Salma Khadra Jayyusi shows how the poetry of Tawfiq Zayyad. and Samih al-Qassim came "provided Arab readers with a potent verbal weapon against the tragic circumstances of their people", how they were "exultantly received" and had "become household names" (21). In addition to the idea of writing from within- which informs their choice of topics, images and motifs, and producing militant poetry that went hand in hand with their political activism, the two poets shared a common destiny of "censorship, banning of books, jailing, torture and assassination" ( Gohar 230) .

A descendent of a Druze family from Rameh in the Upper Galilee, Samih Al Qassim was born in Jordan while his father was serving in the Arab Legion. Al Qassim's family soon moved to

(Deleuzian Discursive Reterritorialization..)Dr. Naglaa Saad M. Hassan 
their home town where he attended primary school. Al Qassim's green years, therefore, were marked by the fresh memories of Nakbah especially that his family did not flee Rameh with the first Palestinian exodus of 1948. In his book About Principles and Art, he illustrates: "while I was still at primary school the Palestinian tragedy occurred. I regard that date as the date of my birth, because the first images I can remember are of the 1948 events. My thoughts and images spring from the number 48" (AlUdhari 50). After graduating from secondary school in Nazareth in 1957, he studied in the Soviet Union for one year. He then started a career of teaching which he soon relinquished and devoted himself to literary and journalistic work. Al Qassim published his first collection of poetry Mawakib alShams (Processions of the Sun) when he was eighteen years old. Discursive resistance was soon wedded to political activism when the young Al Qassim refused to be enlisted in the Israeli army writing to the then prime minister David Ben- Gurion, "declaring that he was in fact born for poetry and not for the gun" (Brown). Al Qassim was particularly influenced by Pan Arab Nasserism whose failure following the Six-Day War had radically shaken his beliefs. Disillusioned with Arab nationalism, Al Qassim, like Mahmoud Darwish, joined the Israeli Communist party Hadash and fostered his activist role by writing for the Israeli daily newspaper Al Itihad along with Al Jadid, Index and others, activities which brought him a steady chain of jailing, house arrests, book confiscation and job dismissals. Notwithstanding this clampdown, Al Qassim continued to write and re-write, to recite poetry and march in protests, to release articles and republish previously banned volumes of poetry, hence enriching not only Palestinian resistance poetry but also Palestinian crisisinflicted psyche.

(Deleuzian Discursive Reterritorialization..)Dr. Naglaa Saad M. Hassan 
Similarly, Tawfik Zayyad, Palestinian poet, scholar and politician, had wedded his sharp zealous poetry to his fierce activism. In elegizing him, Mahmoud Darwish wrote that Zayyad " moved from the poem to the demonstration, to the cell, to the space of language. Zayyad was phenomenal, inspiring people with zeal and gusto" (Masrawy). To the same effect, Waleed Khleif and Susan Slyomovics rightly contend that it was Zayyad who first took up "the mantle of the poet as the conscience of the community" (200). Zayyad was born in 1929 in Nazareth where he, like Al Qassim, had received his secondary education. Zayyad's penchant for politics and poetry was demonstrated as early as his school years. As Riad Masrawy reports, in 1946 he "led a student demonstration protesting British colonialism in Palestine and calling for Palestinian independence". Like Al Qassim, he also travelled to study Russian literature and language in Moscow. After returning home, Zayyad dedicated himself to political and discursive work, joining the communist party Palestine 48 Rakah, participating in protests while, in the same breath, continuing to write articles and enflaming poems. In 1973, Zayyad became the head of the communist party Palestine 48 Rakah and was soon elected to the Knesset on the party's list. In 1975, he was elected Mayor of Nazareth, a position which he kept till his suspicious death in 1994. In his capacity as a Parliament member, Zayyad had pressured for a change in Israeli policies towards Palestinians and was keen on disclosing Israeli crimes to the international community ${ }^{2}$. While holding such political posts, Zayyad continued to organize and participate in protests, acts

\footnotetext{
${ }^{2}$ One of Zayyad's most famous acts was the report he co-authored on Israeli use of torture in Palestinian prison- such report was submitted to the United Nations in 1987 and was hence described as "Perhaps the best evidence of the truth of the reports describing the repugnant inhumane conditions endured by Arab prisoners"[4].
}

(Deleuzian Discursive Reterritorialization..)Dr. Naglaa Saad M. Hassan 
which made him and his family targets for Israeli assaults, arrests and harassment acts on top of which was an unexplained assassination attempt in 1977. In addition to the fundamental role he played in the "Land Day" strike on March 30, 1975, "when thousands of Palestinian Arabs demonstrated against confiscation of Palestinian land and the judification of the Galilee" (Fourikis 90), Zayyad was also a key element in the 1982 Sabra and Shatila strike, the 1992 strike and the 1994 Ibrahimi mosque massacre strike. A forceful example of the steadfastness (Somoud) ; Zayyed continued his activist struggle until he met his end in a head-on collision in the Jordan Valley while returning from Jericho after welcoming Yasser Arafat back from exile.

\section{Strategies of Discursive Re-territorialization in Al Qassim's and Zayyad's Poetry}

A close reading of Zayyad and Al Qassim's oeuvre shows that their project of discursive re-territorialization is enacted by certain-almost common- strategies primary among which are the inscription of Palestine as a homeland and the naming of spatial mostly Israel-deterritorialized- Palestinian landmarks ranging from cities to coffee shops, from villages to houses. Notably, the first strategy is in line with the political agenda of Palestinian resistance given that the first article of the Palestinian National Covenant (Al Mithaq - $\mathrm{Al}$-Kawmee Al Philisteeni) states "Palestine is the homeland of the Arab Palestinian people, it is an indivisible part of the Arab Nation" (Baracskay 42). The second strategy reflects a common tendency in the post-Nakbah Palestinian poetry. As Joe Cleary reminds us, in addition to the confiscation of Palestinian land and its transformation into settlements, there is the act of "re-naming it in the Jewish language" (193). Palestinian writers, therefore, had to struggle against the effacement not only of space but of memory as well,

(Deleuzian Discursive Reterritorialization..)Dr. Naglaa Saad M. Hassan 
undertaking what James Clifford calls "textual rescue". By writing down Palestine as a homeland, the two poets enhance the existence of Palestine as a country and Watan in the memory of emerging generations at both national and international levels. Similarly, by naming and re-inscribing various places which were destroyed, re-named or re-inhabited by Israelis, the poets fight against the threat of effacing cartographical memory, one of the main objectives of Israeli de-territorializing mechanisms.

\section{The Homeland (Watan) as a Dominant Motif}

As mentioned above, at the heart of both $\mathrm{Al}$ Qassim's and Zayyad's discursive re-territorializing enterprise is their relentless effort to write down Palestine as a homeland. Notwithstanding its occupation and partial effacement, and despite the forced displacement and exodus of its natives, Palestine is inscribed in the two writers' poetry as a cherished homeland. In some poems, the poets are bent on attaching themselves to an unnamed watan (homeland), a fact particularly evident in the repetition of the phrases Watani (my homeland) and biladi (my country). In using these words, both poets follow a strategy which, as Barbara Mckean Parmenter puts it, had sprouted in the early twenties of the last century. Parmenter shows how Palestinian poets used a variety of Arabic terms ("Bilad (country), watan, (homeland), mawtin (native place), ... and ard (earth, land) to "invoke the land", how these terms were used "in a generic sense to insure a feeling of national belonging... [how] the land entered a realm of rhetorical abstraction where it could be poetically enriched by the blood of martyred sons or despoiled by ruthless enemies" (36). In addition to using these words as dominant motifs, the poets , adhering to a common strategy in Post-Nakbah Palestini an poetry, tend to personify the homeland, mostly as a mother, an image which further intensifies the umbilical bond tying the persona to his land.

(Deleuzian Discursive Reterritorialization..)Dr. Naglaa Saad M. Hassan 
This strategic motif can be traced in a considerable number of poems in Al Qassim's prolific oeuvre. His poem "If Only" opens and closes with the persona deliberately using the word "my homeland":

Oh you, my homeland, an earring dangling

From the ear of the earth

Oh you, my homeland, a woman opening

her thighs for western wind!

O you my homeland, the oars of a boat!

$\mathrm{O}$ you my homeland, the absent son.

Would you someday rouse in me what is dormant?

Would you just become ... an ordinary homeland?

The use of apostrophe, with its concomitant personification of the country as a flesh and blood human being, throws upon the poem a highly dramatic charge. To further bolster up the intimacy and affability between them and to hammer forth the dilemma of dislocation, Al Qassim, like other Palestinian poets, uses the motif of the land-as-woman and the woman-as-land. Although some critics tend to view the dominance of the land-as-woman motif in Palestinian nationalistic literature as, "a masculinist trope of territorial protectionism" which affirms "male rather than female agency," the motif is particularly fruitful in enhancing the idea of umbilical relationship with the cherished homeland and the "ancestral claims to the land" (Ball 33). Hence, in a complex two-fold metaphor, the country is imaged as a woman who is subject to violation and rape by the storm- like settler/colonizer. By using the image of rape, Al Qassim also links himself to a long line of anti-colonial writers who "view it as a metaphor for the colonial exploitation of the land" (Ball 33). Still, in a reverse imagistic turn, the poet compares the country to a lost son, with

(Deleuzian Discursive Reterritorialization..)Dr. Naglaa Saad M. Hassan 
the effect of keeping the blood relationship on the one hand and underscoring the care and concern the poet feels towards the afflicted motherland on the other. In the ebb and flow of imagery, the homeland is eventually imaged as a forceful inspiring muse capable of awaking what has long been dead inside the persona.

"Excerpts from an Inquisition" is another forceful example supporting this reading. Again, even though Palestine is not overtly named, it projects out as the source of meaning and entity for the Palestinian persona. This is displayed through a highly charged dramatic dialogue in which the Palestinian persona, despite the stressful examination apparently conducted by an Israeli officer, keeps repeating, in an unyielding tone, that the country, with its topographical and natural features, belongs to him:

-And what do you call the country?

-My country

-So you admit it?

-Yes, sir, I admit it.

I'm not a professional tourist!

-You say "my country"?

-I say "my country".

-And where is my country?

-Your country!

-And where is your country?

-My country?

-And the thunderclaps?

-Neighs of my horses..

-And the wind's gusts?

-My own extensions

-And the fertile plains?

-My toil and tears.

-And the mighty mountains

-My hubris

(Deleuzian Discursive Reterritorialization..)Dr. Naglaa Saad M. Hassan 
-And what do you call the country?

-My country.

-And what do I call my country?

-My country....

The poetic and stylistic features of the poem strongly enhance the thematic perspective. Of primary significance is the use of dialogue which accelerates the rhythm and intensifies the zealous tone. The generic noun "the country" (al belad) which initiates the poem is trailed by the noun phrase "my country" excessively (six times) repeated by the Palestinian persona. When the word beladi (my country) ceases to exist, the possessive pronoun is abundantly used in relation to natural and topographical characteristics. The effect is not only to emphasize the umbilical bond tying the persona to his country, the nourishing source of his being and pride, but to drive forth his insistent desire to possess, if merely at the discursive and symbolic level, the physically deterritoriliazed country. No wonder, therefore, that in the tug and pull of the dialogue, the Israeli speaker's question "and my country?" is answered by the rhetorical question "your country!" In a further deconstructive turn, the poet persona is careful to declare that he is not "a professional tourist". Al Qassim's struggle against his classification as a tourist, non-sedentary subject reflects a common attitude experienced by those Palestinians who opted to reside in what came to be known as Israel. As Susan Slyomovics rightly puts it, Palestinian resistance poetry "confronts most directly the painful paradoxes at the heart of Palestinian identity: the predicament of a people, the Palestinian Arabs within Israel, who are forced to be strangers and tourists in their own landscape" (171). If the Israeli mechanisms have changed Palestinian natives from sedentary subjects to nomads inhabiting an ever-shifting space, the persona defies this

(Deleuzian Discursive Reterritorialization..)Dr. Naglaa Saad M. Hassan 
categorization by this open declaration, which reflects a deeprooted (sedentary) rather than a transitory (nomadic) relationship with the land.

The same thematic and imagistic line is carried over in $\mathrm{Al}$ Qassim's poem "Five Star", in which the still unnamed homeland is first metonymically represented by a village which shortly metamorphoses into the selfsame unnamed country.

From the still bloodied star

He looked upon the ashes of earth,

And shouted: "Mohamed Al Aabed,

Because you were only a small village

With mud houses,

A mill on a stream,

With goats cluttered on motionless

Foothills under November drizzles,

And some bare-footed children

in the vineyards of almonds, pomegranates and figs.

The pastoral simplicity and virgin exquisiteness celebrated by the poet underlines, if in an indirect way, the negative impacts of the de- territorializing mechanisms undertaken by the colonizer. That poverty, symbolized by the barefooted kids and enhanced by the emphatic statement that his was not a five-star homeland, blatantly evinces the persona's attachment to and his lament over the lost deterritorialized land. Despite its simplicity and lack of means, the country nourishes his self-esteem, a fact which becomes all the more apparent when his attitude towards his country is set vis a vis that of the colonizer:

Because you were not a five-star homeland, They gave away your wheat ears for locusts, traded the old house's sugar

(Deleuzian Discursive Reterritorialization..)Dr. Naglaa Saad M. Hassan 
For two handfuls of salts,

And sold your tattooed arm.

Because you were not a homeland

Suiting foreign accents,

They wept over you in false movie tears

Over a glass of iced whisky

Around the hips of a belly dancer

Who shakes her body that they may laugh

And then she cries... alone cries

When behind her she slams the doors shut.

Because you were not a homeland,

They left with no appointment

To come with no appointment.

As if you were at the ends of the earth

A fanciful loose-locked inn,

Or a public restroom.

Let them, then, dwell in a time

Grinding out of time.

And be what you wish to be, my homeland

And be what you wish to be, my homeland.

Because you are still a five-star homeland,

I roam the world

To return back to your tattooed arm.

Because you are still a homeland.

Because you are still ... my homeland.

Images of giving away "whe at ears for locusts", of trading "the old house's sugar" for "salts", and of selling "the tattooed arm" entwine with those picturing the drunk colonizer with fake tears over a glass of wine to hammer forth the disparity of attitudes towards the land. Just as the case in the previous poem, the poet relies heavily on repetition, particularly of the word "homeland", to counterbalance the physical state of dispossession

(Deleuzian Discursive Reterritorialization..)Dr. Naglaa Saad M. Hassan 
imposed on him. Images of the country as a public place, a "restroom", or a "loose-locked inn" through which is described the Israeli attitude towards the country contrast sharply with that of "homeland" which is increasingly repeated to reach its highest crescendo in the final lines. In Deleuzian terms, such images succeed in discursively disturbing the Israeli attempt to turn its own nomadic subjects- coming as they are from various spatial points- into sedentary subjects. The Palestinian subject, on the other hand, is pictured as a nomad, one who willingly or unwillingly roams the world. Despite this forced state of nomadism, however, the country, as the poet is careful to stress, is, contrary to the case of the Israeli settler, his homeland. That the poem ends with the poet persona twice asserting "you are still a homeland" leaves the message irrevocably registered.

The same thematic and technical attitude can be traced in the poetry of Tawfik Zayyad. Like Al Qassim, Zayyad is careful to inscribe Palestine as a homeland, a fact which is also technically enhanced by the use of lexical repetition and intensive visual imagery. What distinguishes Zayyad's poetry is the highpitched, deeply passionate and highly defiant notes, not to mention the simple everyday life diction and the intensive songlike musicality. As Bassam Frangieh rightly contends "so powerful is their language and so enchanting their musicality that [Zayyad's] poems have been an enduring source of inspiration and spiritual strength... [and] an integral part of Palestinian resistance ideology" (3). In more than one poem, the reader can listen to the poet persona addressing his country using the words "watani" and "beladi", asserting that she "will survive / forever" , and exploding the sedentary relationship that the colonizer may claim to his country :

What I know is that the right cannot perish

Or be defeated by encroachers

(Deleuzian Discursive Reterritorialization..)Dr. Naglaa Saad M. Hassan 
And on my land the conqueror cannot stay.

Like other Palestinian poets, Zayyad occasionally plays on the symbolism of turab ("dirt" or "soil") to support his claim for the land. Hence, in "Stronger than the impossible", the poet persona calls out: "This soil is ours / despite long nights/ I watered it with my blood and tears." In "Ibn Ammer Valley", the same cry reiterates: "My land... my soil/ my stolen treasure. My history/ the bones of my fathers and ancestors". Likewise, in "With my Teeth", the poet manipulates the image of soil to drive forth his sedentary relationship with the Palestinian territory.

I will stay

I will remain

I will protect every inch of my homeland's soil

with my teeth

I will never accept another substitute.

The tight link tying the speaker to the land is enhanced by the use of synonyms (the verbs "stay" and "remain", and the nouns "soil" (turab) and watan "homeland", the defiant metaphor of teeth and by the blatant statement in the final line which all leave the message irrevocably registered.

In "Free and Just", the poet, after reassuring his country's children that it is for them that they "have defended / the roots of figs and olives"/ the stones/... the house" and asserts his people that the "flags will never fall down," he reiterates: 
My homeland, it is for you that

Our souls are sacrificed.

My homeland,

You are the sweet hope.

Immediately afterwards, and in a chain of images reminiscent of those delineated in Al Qassim's "Excerpts from an Inquisition", the poet, using the assertive generic statements, defiantly declares:

This land is my homeland

Its sky are my longings

it is my present, my future,

my birth and death

my flesh and blood

My heart and ribs

my mother and father

my sons and ancestors

my songs, and my flags,

my glory, and my legacy

My soaring house... my challenge.

The chain of successive images is enhanced by the use of antithesis, which -besides adding up to the musicality of the poem- and hence attracting the reader's attention and tapping into his/her psyche and soul, betrays the poet's desire to accumulate as multiple attributes of his country as possible. Like Al Qassim, Zayyad tends to rely on intensive use of possessive form which reflects the deep passion and the oneness characterizing their relationship.

In "Words for the Homeland", the inscription of Palestine as a homeland is accentuated by the use of visual

(Deleuzian Discursive Reterritorialization..)Dr. Naglaa Saad M. Hassan 
imagery marking its natural and topographical specificity:

As always you will remain, my homeland,

Present in oleander leaves

In the Jasmine scents

In figs... in olives

In Mount Tur

In thunder, in lightning

in rainbows.

In songs of the loyal

on lips of the pious

In green hearts ....in chests

In all eyes

As always, you will remain

My homeland,

Present

Every time

In all times

As always, you will remain

My homeland,

Present in every wound

In the hearts of the rebels

In the images of the dead

In the will of the martyrs

In the mornings.

In the songs of struggle

Shlomo Sand illustrates how "the transition from nomadism to sedentary settlement first took place around the alluvial soil left by rivers, which improve the land for agriculture...[how] [g]radually and increasingly, the sedentary way of life became familiar" concluding that " it was the cultivation of land that

(Deleuzian Discursive Reterritorialization..)Dr. Naglaa Saad M. Hassan 
alone provided the basis for the development of territorial civilization" (38). In this light, in discursively re-terrioritalizing his country and emphasizing his sedentary relationship with the land, Zayyad, is careful to foreground its floral peculiarities as well as its topographical landmarks. Hence, the reference to Mount Tur and the intensive use of floral imagery of figs, olives and Jasmine as icons of identity for the addressed homeland. To this effect, Sus an Slyomovics maintains "Palestinian poets depict "rural life in order to emphasize the Palestinians' close link to nature and the land [which] is "an element in their argument for Palestinian self-determination" (174). In addition, for Zayyad, the definition and the re-possession of Watan is inseparable from its own native people. Hence images of children with their dolls, of boys and youth, of some singing and others praying, of those who rebel and others who had already sacrificed their lives.

In other Zayyad's poems, the image of watan is consciously linked to textuality itself. In his poem "Words", for instance, the poet persona declares his possessions in front of the world proclaiming:

Except for writing poetry

Burning a fire

And describing the future

I don't have anything.

Except for the soil of my homeland

The sky of my homeland

And the flowers of my homeland,

I don't worship anything.

Except for the toiling people

the simple normal people

I don't sanctify anything

(Deleuzian Discursive Reterritorialization..)Dr. Naglaa Saad M. Hassan 
The reference to poetry as one of his possessions, ties land, people and text in an inseparable trinity. He is conscious that his poetry, through which he writes down the pains of his people and tries to re-possess what is denied to him, to re-claim and reterritorialize his country -is his principle war machine. Like al Qassim, Zayyad relies heavily on repetition which together with the simple diction and lucid images accentuates the poetic effect.

\section{Re-Inscribing Spatial Landmarks}

The second strategy through which the two poets attempt to re-territorialize their country hinges on naming and representing spatial landmarks ranging from cities to coffee shops and from villages to houses in a way which tends to revive cultural memory and enhance the spatial identity of the country. In this light, Slyomovics rightly contends that "the challenge for the Palestinian writer anywhere is to articulate a sense of place and to maintain that place for new generations... [and that] one way to maintain it is ... to define ethnographically, sociologically and demographic ally the landscape of the pre-1948 village" (173). Hence, the articulation of place is entangled with its wounds, sorrows, habits and inhabitants with the cumulative effect of keeping in mind the nature of the Palestinian place.

In $\mathrm{Al}$ Qassim's poetry, the representation of places alternates between generic and specific: while in some poems, a universal image of unnamed cities and villages is presented, in others, a more specific portrait of demolished villages and cities predominates. In "Story of a City", the anonymous city is used to metonymically refer to the dilemma of the whole country:

There was a blue city

That dreamt of foreigners

Lazing about its corners

(Deleuzian Discursive Reterritorialization..)Dr. Naglaa Saad M. Hassan 
and spending money day and night

It has become a black city

That despises foreigners

Rounding its cafes

With their rifles' muzzles

The play on the symbolism of visual colours to hammer forth the change of fortunes the country went through is highly effective. The change from blue to black is a transformation from purity and peacefulness to turmoil and crisis. Significantly, the poet uses the word foreigners "aganeb" to refer to the settler/colonizer which reflects his keenness to deny Israelis the right to have a tight sedentary bond with the land. For him, despite the foreigners' intimidating practices, evident in the image of rifle muzzles- their relationship with the land is ephemeral; he discursively establishes them as Deleuzian nomadic rather than sedentary.

In other poems, Al Qassem enacts his discursive reterritorialization by naming places which were totally demolished, such striated spaces that were forcefully turned into smooth spaces only to be turned again into striated ones. In "There was a Village Called Sirin," he re-envisions, and discursively memorializes the village of Sirin, which was depopulated and totally destroyed in 1948. In the poem, Al Qassim captures the image of effacement by mingling reality with fiction, the mundane with the sacred heavily relying, as typical in his poetry, on visual imagery and highly charged diction:

There was a village called Sirin

Nothing remained of Sirin after the auction,

Apart from you, little prayer rug

Because a mother slyly stole you

And wrapped up her son who'd been sentenced to cold

And weaning- and later to sorrow and longing

(Deleuzian Discursive Reterritorialization..)Dr. Naglaa Saad M. Hassan 
It's said that there was a village, a very small village,

On the border between the sun's gate and earth It's said that the village was twice soldOnce for a measure of oil And once for a kiss through a pane of glass.

At the fictional level, the city is first portrayed as a place situated between the sun and the earth, an image which reflects the poet's soaring passion and the romantic eye with which he perceives the symbolic city. It is then depicted as a commodity which is twice sold: once in an auction and once in a barter market in return for a kiss, a two-fold image which underscores the carelessness with which the city, along with its spatial contours and its people, was handled. The remaining rug addressed by the poet is a typical Al Qassim's motif: in most of the poems tackling the aftermaths of Israeli attacks, the poet either describes or addresses some remaining, mostly inanimate object. The little prayer rug with its connotation of submission to God unites with the image of the defenseless baby to accentuate vulnerability and powerlessness. As the poem proceeds forward, the fusion of fiction with reality renders the picture ambiguous and adds up to the overwhelming gloominess:

The buyers and sellers rejoiced at its sale, the year the submarine was sunk, In our twentieth century And in Sireen-the buyers went over the contactWere white-washed houses, overs and trees, Folk poets, peasants and children.

But there was no school-

And neither tanks

Nor prisons.)

The threshing floors, the color of golden wine, 
And the graveyard

Were a vault meant for life and death,

And the vault was sold!

The explicit reference to the twentieth century with its submarines and tanks snatches the city away from the fanciful world. In fact, it sheds light, albeit indirectly, on the violence lying behind the demolition of the symbolic city referring, in the same breath, to the destructive deterritorializing Israeli mechanisms. The reference to the vault shows how Al Qassim, in his keen attempt to re-gain and re-territorialize Palestinian places, moves from the generic to the specific, from the village to the house. Indeed, the symbolic vault reflects a steadfast commitment to attach one's identity to the nuances of the Palestinian place.

In "Karmael", Al Qassim further revives the national collective memory by registering the massive deterritorializing Israeli acts through which new cities were built upon the rubbles of old Palestinian villages. As commonly known the city of Karmael was built after the expropriation the land of the Arab villages of Deir al Asad, Bi'ina and Nahf and the evacuation of its inhabitants. Referring to the notorious Karamel as "the city of envy, hunger and skulls", the poet writes

Mornings and evenings

We are caught by her face and the sky.

And we smile not like fools ..but like prophets

When confronted by a petty crucifier

who veils the suns with some cloth!

**

Tomorrow, O palaces that in graves anchored

Tomorrow, o parks, o hardships

Tomorrow, this soil will remember

(Deleuzian Discursive Reterritorialization..)Dr. Naglaa Saad M. Hassan 
How we granted her the colour of blood

These rocks will remember

The shepherds who put them up

with hymns and lyrics

And they will remember that we....

$* * *$

Here ... our genesis comes into being;

Here, comes their genesis to an end.

The poet plays on religious imagery to write down the distressful reality of their effaced land and to show the powerlessness of Palestinian people in face of the massive deterrritorializing Israeli acts. Hence, while the colonizer is a crucifier, the defenseless evacuated people are prophets and the very acts of de and reterritorialization and exodus and settlement is, in its very essence, "genesis". Despite bitterness and gloom- evident in the persona's lament over palaces and graves, - the poet is careful to reiterate his umbilical bond with the land with its "rocks" and "soil" itself watered by the people's very blood.

Careful to struggle against the potential effacement of collective memory, Zayyad writes down not only the names of places which were demolished but also those that are still existing. His project of spatial re-inscription is openly stated in his poem "The Olive Tree":

I shall carve the serial number

Of every stolen piece of land

The place of my village on the map

And the blown-up houses, $[\ldots]$

For the sake of remembrance,

I shall continue to carve

All the chapters of my tragedy

(Deleuzian Discursive Reterritorialization..)Dr. Naglaa Saad M. Hassan 
And all the stages of Al- Nakbah

On the home yard olive tree!

In some poems, the cities named are connected with some historical disasters such as the case in "Kafr Qassim", in which the poet chronicles the massive notorious massacre:

Have you heard the latest epic ?

and how men like beasts

were slaughtered ?

and a people's tale called:

"the harvest of skulls"?

and the stage was a village

called Kafr Qassim!

In other poems, Zayyad ties the names of cities to the Deleuzian idea of Palestinians as sedentary subjects. "Here we will remain" is a remarkable case in point:

We shall remain

Like a wall upon your chest

We shall remain

A wall on your chest

We shall remain

Singing our songs

Taking to angry streets

Filling Jails with dignity

In Lidda, in Ramla, in the Galilee, we shall remain, guarding the shades of figs and olive trees, and like yeast in dough fermenting rebellion in our kids 
In Lidda, in Ramla, in the Galilee, we shall remain.

The repetition of the cities' names - which serves as a refrain initiating and closing the poem- goes hand in hand with that of the verb "remain", which forcefully reveals the poet's keenness to underline the sedentary relationship tying Palestinians to their land. Despite the exodus of huge numbers of Palestinians, those who remain, though experiencing a state in-country exile, sustain the idea of Philsteen as a homeland.

In "Ibn Ammer Valley", Zayyad records the massive transformation of space undertaken by the Israeli forces in the valley carrying the same name. Known for its high fertility, the inland Ibn Ammer valley (in Hebrew Jezreel Valley) has been subject to fierce spatial and demographic de- and reterritorialization with the Israeli colonizer snatching whole villages from the Palestinian grip and re-constructing them into settlements. In his poem, Zayyed not only emphasizes the Arab nature of the valley- informed by the very use of the Arab namebut also discursively records the effacement of certain villages which once belonged to the Arabs. In a highly charged apostrophe, the poet is heard talking to the valley itself lamenting over the demolished places:

Our dark villages

Had turned into ruins

And rough relics.

And the one that remains

Is still resisting

The fangs clutching her neck

And sucking paradise

out of her blood

Don't tell me... Don't tell me

Even graves were turned upside down!

(Deleuzian Discursive Reterritorialization..)Dr. Naglaa Saad M. Hassan 


\section{Graves .... upside down!}

The poet plays on animate and inanimate imagery to hammer forth the atrocity with which the valley's spaces were handled. The image of ruins and relics with its connotations of lifelessness, destruction and effacement are followed by those comparing the colonizer to a monster on the one hand and the village to a victimized human being on the other. The effect is to augment the negative impacts of the massive deterritorialzation acts and the violence with which they are undertaken.

At a microcosmic level, Al Qassim's and Zayyad's enterprise of writing down places as a tool of discursivereterrritorialization is enacted by naming smaller spatial landmarks such as houses and cafés. Commenting on the penchant for minute description of places- particularly the housein Palestinian poetry, Slyomovics shows how "architectural details emerge from every line of verse to make real those familiar things that have been given alienating function" (176). By representing these places, the poets are in fact shielding themselves, as well as their fellow people, against the threat of forgetfulness; it is through these memories inscribed in texts that elements of space are eternalized and armed against alienation and loss of identity. In addition to the minute description of architectural specificity, the poets, as will be evident in the poems analyzed below, are careful to underline the social dimensions associated with the place described.

In Al Qassim's poem "Our Café", the poet persona raises memories of an unnamed café which used to be his nesting place. The poet's ideological view is exacerbated by the typical use of symbolic diction, visual imagery which are together enhanced by a gloomy mournful tone. The de-territorialized café is not a set of walls devoid of life, of love, of nature; it is a place which harbors humans as well as birds, physical objects as well as abstract ones:

(Deleuzian Discursive Reterritorialization..)Dr. Naglaa Saad M. Hassan 


\section{Our Cafe}

A day, an hour, a second ago,

Twenty years ago,

Our cafe was a dreamy cloud-dwelling wing.

Amidst its crawlers we had two chairs,

Roses and youth.

A day, an hour, an eyelid flutter ago,

Twenty years ago,

A swallow nested in our café's corner,

And sprayed us with its sweet scent.

And we relished absence

Amidst two glasses,

Some twig-like smoke and butterfly fogs

*

Twenty years later

Memories of the sored moment

Snatched me from the chronic details of life

Towards our café. But I did not find it.

I wish I had not gone back there.

The effacement of space is paralleled by the demolition of time. Hence, in the persona's perception, "twenty years" is not different from a second (an eyelid flutter ago." The space of the café solidly lodges in his memory with visual and auditory images relentlessly fighting the passage of time and the reality of absence. That the cafe was a dwelling nest for the sweet-scented sparrow does not only throw a romantic aura upon the scene but also enhances the destructive effects of the Israeli deterritorializing acts which reached humans and other beings.

In his study of the relationship between identity and the Palestinian house, Ziad B. Senan shows how "people usually personalize their house through the building itself, as well as through the landscape in which it is set and the furniture it contains as a means of expressing their distinctiveness" (4).

(Deleuzian Discursive Reterritorialization..)Dr. Naglaa Saad M. Hassan 
Expectedly enough, the Palestinian house along with its surrounding landscape occupies a central place in the discursive project of both Al Qassem and Zayyad. In addition to including the house as a constant image and motif, a fact evident in some of the poems tackled in the previous sections- many poems thematize the surrounding landscape- particularly the tree- as a substantial element of the country's spatial identity. Examples of both approaches are to be found in the works of both poets. In a two-line poem, Al Qassim presents the tree as a symbol of rootedness and a territoriality which is not liable to the continuous spatial transformation inherent in the continuous de and re territorialization. He writes

Leaves change from time to time

But the oak trunk.....

Similarly, in Zayyad's "On the Trunk of an Olive Tree", the treepart of the house's courtyard- emerges as a symbol of spatial identity, fighting as she is, the massive transformation of land. The poet writes:

Because I do not weave wool

And every day I'm threatened by arrest

And my house open to frequent police visits

Rummaging and cleansing.

Because I am unable to buy paper

I shall carve all that has happened

All my secrets

On an olive tree

In the courtyard of the house

I shall carve my story and all the seasons of my tragedies

My sighs, 
My grove and the tombs of my dead I shall

The olive tree is not only defying spatial transformation- being as she is one of the economic war machines both in the deterrirtorialized Palestine and the colonizing Israel- but it is also a repository of woes, wounds and secrets. The tree is the book of memory holding all the disasters and the upheavals which flesh out the skeleton of history.

Prominent among Zayyad's pertinent verse is the following poem in which is presented a typical picture of the Palestinian house:

The house, big and spacious, standing since the fourth forefather, In the ceiling some pigeons nesting, In the air the scent of past days, and the wells of stored oil, And the fragrance of lilies and thyme, And the smoke of burned tobacco.

Around dough stove some women sitting and kids of different ages laughing and some youth joyfully fun having And old men around the brazier circling And far away in a dark corner a twenty-year-old mother is perching

Rather than concentrating on the architectural specificity of the Palestinian house, Zayyad centers on its social and psychological dimensions. In fact, he conforms to Robert Porter's view of the house "as a malleable aesthetic form capable of creating "sensory qualities" or sensation (colour, light, sound) to an architecture of the outside" (81). Hence the spaciousness of the house is entwined with the plants' colours and scents ('thyme and lilies")

(Deleuzian Discursive Reterritorialization..)Dr. Naglaa Saad M. Hassan 
and the sounds of the youth's fun couple with the kids' laughter. What we have is a blend of visual (the house, the ceiling, pigeons, kids, old men, woman), auditory (laugh, entertaining), kinesthetic (joyfully, having fun, laughing) and olfactory imagery ("the scent of past days", "fragrance of lilies and thyme", "the smoke of burned tobacco")- which all add up to the vividness associated with the house described. The house is a nesting place for birds, and a milieu of social gathering for people of different ages and sexes. The inclusion of lilies, thyme, dough stove along with pigeons underlines the role played by particular elements of fauna and flora in the definition of domestic space in the Palestinian context.

\section{$* * *$}

The above analysis makes it crystal clear that the poetry of both Al Qassim and Zayyad offers a rich platform for the applicability of the Deleuzian concepts related to space and that their poetry offers palpable examples of discursive resistance from within occupied Palestine. Through their rich poetry, the two poets were able to discursively confront the continuous acts of deterritorialization effected by the Israeli colonizer. The intensive use of the motif of homeland (Watan), the naming of demolished cities that once existed as striated spaces in the Palestinian local map and the writing down of certain spatial landmarks are all meant to counter-act the colonizer's attempt to deface not only the land but also the memory. The poets' discursive re-territorializing project is also meant to disrupt the state of at-home exile and enforced nomadism imposed on Palestinians. Overall, the discursive acts undertaken by the two poets substantially contributes to the large-scale Palestinian cultural aiming at reterritorializing the land symbolically and conceptually.

(Deleuzian Discursive Reterritorialization..)Dr. Naglaa Saad M. Hassan 


\section{Works Cited}

Abdel Malak, Kamal and Wael Hallaq, ed. Tradition, Modernity, and Postmodernity in Arabic Literature. Brill, 2000.

Abdullah-al-Udhari, trans. Victims of a Map: A Bilingual Anthology.Zed Press, 1984. April 2017.

Al Qassim, Samih. Sadder Than Water

http://www.theguardian.com/books/booksblog/2008/may/19/poe moftheweek39. Accessed July 282018.

Al Qassim, Samih. Al Aa'mal Al Kamelah (Collected Poems).Volume 1. Dar Soad El Sabbah, 2009.

---. Al Aa'mal Al Kamelah (Collected Poems).Volume 2 . Dar Soad El Sabbah, 2009.

---. Al Aa'mal Al Kamelah (Collected Poems).Volume 3 . Dar Soad El Sabbah, 2009.

---. Al Aa'mal Al Kamelah (Collected Poems).Volume 4. Dar Soad El Sabbah, 2009.

---. Al Aa'mal Al Kamelah (Collected Poems).Volume 5 . Dar Soad El Sabbah, 2009.

---. Al Aa'mal Al Kamelah (Collected Poems).Volume 6 . Dar Soad El Sabbah, 2009.

Ball, Anna. Palestinian Literature and Film in Postcolonial Feminist Perspective. Routledge, 2012.

(Deleuzian Discursive Reterritorialization..)Dr. Naglaa Saad M. Hassan 
Baracskay, Daniel. The Palestinian Liberation Organization: Terrorism and Prospects for Peace in the

Holy Land. ABC, Clio, 2011.

Brown, Liam. "Samih Al Qassim and the Language of Revolution.” http://www.middleeasteye.net/essays/samih-alqasim-and-language-revolution-1095441705. Accessed 20 May 2017

Cleary, Joe. Literature, Partition and the Nation-State: Culture and Conflict in Ireland, Israel and Palestine. Cambridge University Press, 2002.

Deleuze, Gilles. "Control and Becoming: Gilles Deleuze in Conversation with Toni Negri." Trans. Martin Joughin.

https://www.uib.no/sites/w3.uib.no/files/attachments/6._deleuzecontrol_and_becoming_0.pdf. Accessed 22 April 2016.

Deleuze, Gilles and Felix Guattari. Anti-Oedipus: Capitalism and Schizophrenia. Trans. Robert Hurley, Mark Seem and Helen R. Lane. University of Minnesota Press, 1983.

---. A Thousand Plateau: Capitalism and Schizophrenia. University of Minnesota Press, 1987.

Elad-Bouskila, Ami. Modern Palestinian Literature and Culture. Routledge, 2013.

Farsoun, Samih K . Culture and Customs of Palestinians. Greenwood, 2009.

Fourikis, Nicholas. I'm Gonna Tell God Everything. Design Publishing, 2017.

(Deleuzian Discursive Reterritorialization..)Dr. Naglaa Saad M. Hassan 
Frangieh, Bassem. "Modern Arabic Poetry: Vision and Reality." in Tradition, Modernity, and Postmodernity in Arabic Literature. Ed. Kamal Abdel Malak and Wael Hallaq. Brill, 2000.

Gohar, Seddik. "Narrative Diaspora and Exile in Arabic and Palestinian Poetry." Rupkatha Journal on Interdisciplinary Studies in Humanities, V. 3, N.2, 2011,228-242.

Hijjawi, Sulafa. Poetry of Resistance in Occupied Palestine . Iraqi Ministry of Culture, 2009.

Isenstadt, Sandy and Kishwar Rizvi, eds. Modernism and the Middle East: Architecture and Politics in the twentieth century. University of Washington Press, 2008.

Janßen, Katja. "Nathalie Handal's "Amerika" Chooses Palestine as Poetic Centre." The SOAS Journal of Postgraduate Research, Vol. 7, 2014, 38-47.

Jayyusi, Salma Khadra, ed. Anthology of Modern Palestinian Literature. Columbia University Press, 1992.

Kanafani, Ghassan. "Resistance literature in Occupied Palestine”. In Poetry of Resistance in Occupied Palestine. Trans. Sulafa Hijjawi . the Ministry of Culture,1968.

Khleif, Waleed and Susan Slyomovics. "Palestinian Remembrance Days and Plans: Kafr Qasim , Fact and Echo" in Sandy Isenstadt and Kishwar Rizvi, eds. Modernism and the Middle East: Architecture and Politics in the twentieth century. University of Washington Press, 2008.

(Deleuzian Discursive Reterritorialization..)Dr. Naglaa Saad M. Hassan 
Hussein, Khalid. Palestine and Modern Arab Poetry. Zed Books Ltd. 1984.

Masrawi, Riad. "Tawfik Zayyad: Voice of His People". This Week September 2009. https://palestine-family.net/tawfik-zayyad-politici Accessed 20 April 2018.

Mckean Parmenter, Barbara. Giving Voice to Stones: Place and Identity in Palestinian Literature. University of Texas Press, 2004.

Nassar, Hala Khamis, and Najat Rahman eds. Mahmoud Darwish, Exile's Poet: Critical Essays. Interlink Books, 2007.

Porter, Brown. Deleuze and Guattari: Aesthetics and Politics. University of Wales Press, 2009.

Robinowitz, Dan and Khawla Abu Baker. Coffins on Our Shoulders: The Experience of the Palestinian Citizens of Israel. University of California Press, 2005.

Sand, Shlom. The Invention of the Land of Israel: From Holy Land to Homeland. Verso, 2010.

Samin, Richard. "From Geography to Semiotics: Visions of Urban Environments in a Few Black South African Novels." http://oracle-reunion.pagesperso-orange.fr/documents/422.shtml. Accessed June 12, 2016.

(Deleuzian Discursive Reterritorialization..)Dr. Naglaa Saad M. Hassan 
Senan, Ziad B. "The House as an Expression of Identity: The Case of the Palestinian House" Forum vol.2, 1993, 3-10.

Slyomovics, Susan. The Object of Memory: Arab and Jew Narrate the Palestine Village. University of Pennsylvania Press, 1998.

Schuster, Daniel James. Resistance Under Occupation: A Palestinian Uyghur Comparison. Anchor Academic Publishing, 2017.

Tucker, Spencer C. The Encyclopedia of the Arab-Israeli conflict: A Political, Social and Military History. Volume 1. ABC Clio. California, 2008.

Zayyad, Tawfik. Al Aa'mal Al Kamelah (Collected Poems). Dar Al Awada, 2000. 


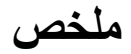

تقدم هذه الدراسة قراءة لمختارات من شعر توفيق زياد وسميح القاسدم -وهما اثنان من



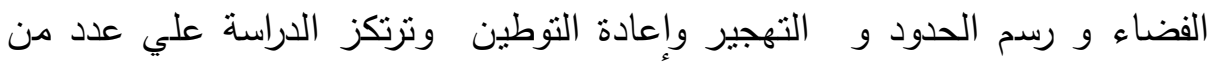
المفاهيم التي وضعها الناقدان الفرنسيان ومن ابرزها الفضاء المقيد


deterritorialization لإبراز أهمية هذه المفاهيم في القراءات السياسية للقضية الفلسطينية و القراءات النقدية لثعر المقاومة الفلسطينية وذللك بهدف اثراء الجانب التطبيقي للنظرية من ناحية واثراء الدراسات الغربية عن الشعر العربي الفلسطيني من خلال قراءة نقدية لصوتين لم يحظا باهنمام نقدي واسع في الأوساط الغربية من ناحية اخري. ومن ثم فان الدراسة

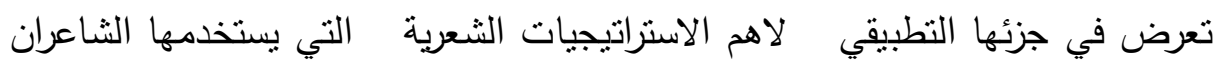




الجغرافية والسياسية من خلال الخطاب الثعري • وبالفحص الدقيق لإنتاج الثشاعرين محل الدراسة نجد انهما يشتركان في الكثير من الاليات التيمية و التقنية في تفعيل


يقومان بإعادة تأسيس حدود الفضاء الفلسطيني التي شوهها المستعمر الإسرائيلي كما

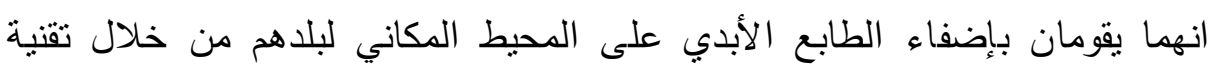

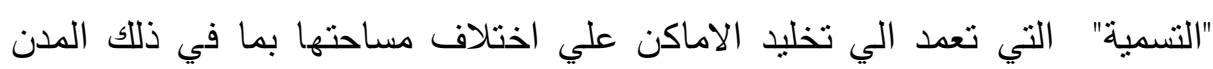
والقرى والمباني التي تم محوها جميعًا من الخربطة المادية.


ديلوز ،التهجير ، إعادة التوطين الخطابي 